\title{
How to mitigate cyanobacterial blooms and cyanotoxin production in eutrophic water reservoirs?
}

\author{
Barbara Pawlik-Skowronska • Magdalena Toporowska
}

Received: 26 August 2015/Revised: 23 May 2016/ Accepted: 25 May 2016/Published online: 8 June 2016

(C) The Author(s) 2016. This article is published with open access at Springerlink.com

\begin{abstract}
Cyanobacterial blooms and cyanotoxin production were studied for 2 years in four hydrologically modified lakes with nutrient-rich waters. We hypothesized that frequency of flushing may considerably influence cyanobacterial blooms. Abundance, biomass and diversity of cyanobacteria as well as cyanotoxins' variability and concentrations (by HPLC-PDA; -FLD) were determined. In two larger lakes, into which nutrient-rich water was supplied once a year, lower cyanobacterial species diversity, higher biomass of Microcystis spp., Aphanizomenon spp., Dolichospermum spp. and higher microcystin (MC) concentrations were found. In the other lakes, with several irregular water-level manipulations per year (alternating outputs and inputs), higher diversity, lower biomass of cyanobacteria and MC concentrations were observed. MC-LF, -LR and -RR produced by Microcystis spp. predominated in the more stable lakes, whereas in the lakes with frequent water manipulations different species of Oscillatoriales developed and MC-LA, -LY, -LW and -WR were also important. RDA analysis revealed that the frequency
\end{abstract}

Guest editors: M. Beklioğlu, M. Meerhoff, T. A. Davidson, K. A. Ger, K. E. Havens \& B. Moss / Shallow Lakes in a Fast Changing World

B. Pawlik-Skowronska $(\bowtie) \cdot$ M. Toporowska Department of Hydrobiology, University of Life Sciences in Lublin, Dobrzańskiego 37, 20-262 Lublin, Poland e-mail: barbara.pawlik@up.lublin.pl of water manipulations was the most significant variable for composition of cyanobacterial communities. The study highlights that a higher frequency of water-level manipulations, which increased flushing rate, was beneficial to nutrient-rich water reservoirs.

Keywords Flushing - Water management · Microcystis · Cyanobacteria diversity $\cdot$ Microcystins

\section{Introduction}

Excessive development of cyanobacteria in nutrientrich aquatic ecosystems presents a real hazard to the health of humans and aquatic biocenoses due to production of numerous cyanotoxins (Codd et al., 2005). Proliferation of these microorganisms may be accelerated by increased water temperature and prolonged water residence time (Elliott, 2010; Romo et al., 2013), although various cyanobacteria species may respond differently to changing environmental conditions. As reported by Reynolds \& Lund (1988), the hydraulic retention time of lakes can be decisive in phytoplankton development. According to the modelling study of Elliott (2010) and statistically elaborated data from 134 lakes (Carvalho et al., 2011), the water retention time is one of the most important factors influencing cyanobacteria mass development. In shallow eutrophic lakes and reservoirs, both waterlevel management and natural flushing have an impact on the trophic status of water bodies; therefore, 
appropriate water-level management can be a decisive element in lake responses, especially (Coops \& Hosper, 2002; Coops et al., 2003; Verspagen et al., 2006; Haldna et al., 2008), where cyanobacterial blooms are a common negative phenomenon (Ballot et al., 2010; Kobos et al., 2013; Pawlik-Skowronska et al., 2013). Water-level fluctuations, both in shallow and deep stratified lakes and reservoirs, are a natural phenomenon (as a result of a seasonal or long-term imbalance between the amount of water entering and leaving lakes) or a result of human activities (Coops et al., 2003; Zohary \& Ostrovsky, 2011). Human exploitation of water increases intra- and inter-annual water fluctuations beyond natural amplitudes. In shallow water bodies, the implications of water-level changes can be crucial and can cause undesirable effects on the biota and on ecosystem functioning (Beklioglu et al., 2007; Bond et al., 2008). Research concerning the influence of water-level changes on biota has focused mainly on the structural shaping of fish, macrophyte and zoobenthos communities (Leira \& Cantonati, 2008; Zohary \& Ostrovsky, 2011). The need for a strategy for mitigating the impact of cyanobacterial blooms is currently of great concern (Pearl, 2014 and references therein); however, there is scant information about the influence of water-level fluctuations and flushing rate on the development of cyanobacteria and their taxonomic variability (Padisák et al., 1999; Romo et al., 2013), which determine the production of biologically active metabolites (e.g., cyanotoxins and enzymatic inhibitors) that are harmful to living organisms (Welker \& Döhren, 2006; Sivonen \& Börner, 2008; Pawlik-Skowronska et al., 2012; Toporowska et al., 2014, Freitas et al., 2015). Especially, in the case of reservoirs providing water for fish farming, field irrigation and recreation, the species composition of cyanobacteria communities and cyanotoxin production are hazardous not only to aquatic organisms, but also to humans.

Here, we present a comparative study of the community structure of potentially toxigenic cyanobacteria and cyanotoxin production in hydro-morphologically modified lakes with different types of water-level management. We hypothesized that frequent waterlevel manipulations, and consequently, increased flushing rate can mitigate the development of cyanobacteria and influence cyanotoxin profiles in lakes.

\section{Materials and methods}

Study area

The study was conducted in four Lakes, i.e., Dratów, Krzczeń, Domaszne (vel Tomaszne) and Białe Sosnowickie (Białe S.), located between $51^{\circ} 20^{\prime} 21^{\prime \prime}-$ $51^{\circ} 31^{\prime} 32^{\prime \prime} \mathrm{N}$ and $22^{\circ} 56^{\prime} 47^{\prime \prime}-23^{\circ} 02^{\prime} 31^{\prime \prime} \mathrm{E}$ in the Łęczyńsko-Włodawskie Lake District (Eastern Poland, Fig. 1). The Lake District is a valuable natural area, where in the 1950s, large hydrological works were carried out, which fundamentally changed the environment. In 1961, the lakes were modified into water storage reservoirs (with a periodically regulated water levels) and included into the Wieprz-Krzna drainage canal system, which supplied distinct, polluted and nutrient-rich waters from the Wieprz River to the lakes (Dawidek et al., 2004). The lakes have been heavily modified; e.g., the surface and embankments of the shoreline have been enlarged (partially in the case of Lake Białe S.) and the water volume can be controlled by sluices. All the lakes are shallow and polymictic, but Lakes Dratów and Krzczeń have approximately twice the volume as Lakes Domaszne and Białe S. (Table 1). In Lakes Dratów and Krzczeń, water loss occurred naturally and only one water supply from the canal per year (in autumn) was conducted by the authorities of the Regional Management Office for Irrigation and Water Systems in Lublin. In the other two lakes, where the waters have been used for fish farming and field irrigation, three to five water outputs and subsequent inputs per year were performed. Data regarding annual water-level fluctuations in Lakes Dratów, Krzczeń and Domaszne were obtained from calculations based on watermark readings. The water re-filling pulse in three lakes was estimated on the basis of the water volume introduced into each lake and the water input rate $\left(2 \mathrm{~m}^{3} \mathrm{~s}^{-1}\right.$ in the larger lakes and $1 \mathrm{~m}^{3} \mathrm{~s}^{-1}$ in the smaller one). No exact data are available for Lake Białe S., where the waters have been used for private activity. In this lake, water outputs and subsequent inputs are frequent, and depend on the needs of fish farming in neighbouring pounds (personal communication; manager of Fish Farm "Polesie" in Sosnowica). Characteristics of biological communities of the lakes were presented previously (Adamczuk et al., 2015). 


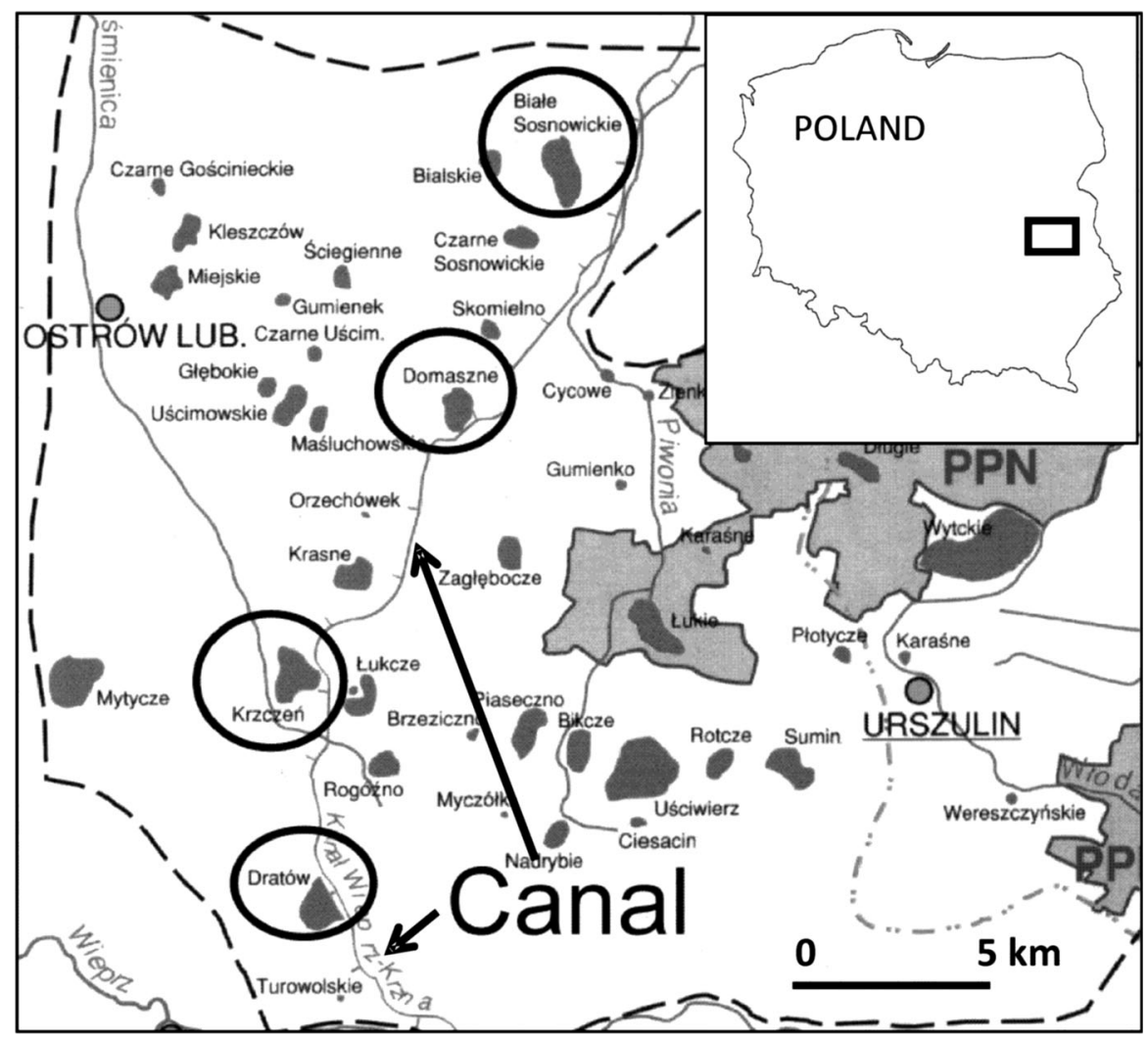

Fig. 1 Location of the studied lakes in the Łęczna-Włodawa Lake District in Eastern Poland

Table 1 Hydro-morphological characteristics of the lakes and their use

\begin{tabular}{|c|c|c|c|c|c|c|}
\hline \multirow[t]{2}{*}{ Names } & \multirow[t]{2}{*}{$\begin{array}{l}\text { Area } \\
\text { (ha) }\end{array}$} & \multirow[t]{2}{*}{$\begin{array}{l}\text { Aver. } \\
\text { depth (m) }\end{array}$} & \multirow[t]{2}{*}{$\begin{array}{l}\text { Max. volume } \\
\left(10^{6} \mathrm{~m}^{3}\right)\end{array}$} & \multicolumn{2}{|c|}{$\begin{array}{l}\text { Refilling pulse } \\
(\% \text { of lake } \\
\left.\text { volume day }{ }^{-1}\right)\end{array}$} & \multirow[t]{2}{*}{ Use of the lakes } \\
\hline & & & & 2012 & 2013 & \\
\hline Dratów & 168 & 2.47 & 4.00 & 4.3 & 4.3 & Water retention \\
\hline Krzczeń & 174 & 2.90 & 4.88 & 3.6 & 3.5 & Water retention \\
\hline Domaszne & 95 & 2.32 & 2.22 & 3.8 & 4.0 & Water retention for fish farming and field irrigation \\
\hline Białe Sosnowickie & 144 & 1.30 & 2.08 & n.d. & n.d. & Water retention for fish farming and field irrigation \\
\hline
\end{tabular}

n.d. no data

Sample collection and physicochemical analysis of water

Water samples (5 L, Ruttner sampler) from the uppermost $(0-0.5 \mathrm{~m})$ layer of water in three sites of the pelagic zone of each lake, once per season (in spring: May or June; in summer: July or August; and in autumn: October) in 2012 and 2013, were collected for the analysis of chemical parameters. Water temperature, Secchi Depth (SD), $\mathrm{pH}$ and conductivity were measured in situ. $\mathrm{N}_{-} \mathrm{NH}_{4}$, $\mathrm{N}-\mathrm{NO}_{3}, \mathrm{P}_{-} \mathrm{PO}_{4}$ and $\mathrm{P}_{\text {tot. }}$ concentrations in the water were determined according to Hermanowicz et al. (1976). Total organic carbon (TOC) and total suspended solids (TSS) were determined using the PASTEL UV spectrophotometer. The chlorophyll-a (chl-a) concentration was determined according to PN-ISO 10260 (2002). 
Water samples $(100 \mathrm{ml})$ for cyanobacteria and cyanotoxin (0.5-1 1) analyses were collected at the same time and positions as those for the physicochemical analyses. Cyanobacterial scum was also collected from the surface water layer in Lake Krzczeń, in both 2012 and 2013.

Cyanobacteria analyses

Quantitative analysis of cyanobacteria was performed on samples preserved with Lugol's solution and then with a formalin/glycerin mixture (3:1). Cyanobacteria were counted using light microscopy in a $1 \mathrm{ml}$ phytoplankton chamber. One hundred micrometers long fragments of filamentous taxa and one colony of coccoid taxa were recognised as individuals. Cyanobacterial biomass was estimated by measuring the cell volume (Hillebrand et al., 1999).

Qualitative taxonomic analysis was carried out on fresh material collected using a $25 \mu \mathrm{m}$ phytoplankton net. Cyanobacteria identification based on key-books (Komárek \& Anagnostidis, 1999, 2000, 2005; Komárek, 2013) was performed using light microscopy. The similarity of the cyanobacterial communities in lakes (estimated at the species level) was compared using the Jaccard index (Jaccard, 1912). The Shannon-Wiener diversity index for cyanobacteria communities was also calculated based on the number of cyanobacterial species and their biomass (Shannon \& Weaver, 1949).

Cyanobacterial biomass lysates

To determine intracellular cyanotoxin concentrations in the lakes, surface water $(0.5-1.01)$ containing cyanobacteria was filtered through Whatman GF/C filters, and extracts of the biomass were prepared in ice-cooled glass tubes in 75\% (v/v) methanol (Merck, pure p.a.) using ultrasonication (2-times for $5 \mathrm{~min}$, $50 \mathrm{~W}$, Sonopuls ultrasonic homogeniser, Bandelin). After centrifugation $\left(14,000 \mathrm{rpm}\right.$ for $10 \mathrm{~min}$ at $\left.17^{\circ} \mathrm{C}\right)$ and collection of supernatants, filters with the biomass were back-extracted (once for $5 \mathrm{~min}$ ), and after centrifugation, the combined supernatants (4.0-4.7 $\mathrm{ml})$ were collected in glass tubes and kept at $-20^{\circ} \mathrm{C}$ until the day of cyanotoxin analysis.
HPLC-PDA analysis of microcystins

A high-performance liquid chromatography-photodiode array detection (HPLC-PDA) system (Shimadzu) was used for microcystin (MC) detection in the cyanobacterial extracts, as reported previously (Pawlik-Skowronska et al., 2013). Microcystins were separated using the following mobile phases: A-water acidified with $0.05 \%$ trifluoroacetic acid (TFA, Merck) and B-acetonitrile (Merck) acidified with $0.05 \%$ TFA (the gradient $30-100 \%$ ) at a flow rate of $0.7 \mathrm{ml} / \mathrm{min}$ using a RP-18 Purospher column $(125 \times 3 \mathrm{~mm}, 5 \mu \mathrm{m}$, Merck). The wavelength range for detection was 200-300 nm. For identification and quantitative analysis, MC-LR, -RR, -YR, -LA, LY, - LW, -LF, and -WR (Alexis) were used as standards.

HPLC-FLD analysis of anatoxin-a

Anatoxin-a (ANTX) was determined in the extracts (prepared as mentioned above) from cyanobacterial biomasses collected in 2012 and from cyanobacterial scum collected in Lake Krzczeń in 2013. ANTX was determined using HPLC with fluorescence detection (FLD, Beckman) according to James et al. (1998) and Furey et al. (2005), with some modifications and without solid phase extraction (SPE) clean-up of extracts. Ten microliters of each extract was reconstituted with $100 \mu \mathrm{l}$ of $0.1 \mathrm{M}$ sodium borate in a $2-\mathrm{mL}$ Eppendorf probe. Fifty microliters of $10 \%$ NBD-F (4fluoro-7-nitrobenzofurazan; Fluka) in acetonitrile was added, and the mixture was allowed to stand (10 $\mathrm{min})$ in the dark at room temperature. Fifty microliters of $1 \mathrm{M} \mathrm{HCl}$ was added to terminate the reaction, and HPLC-FLD was performed using an RP-18 Purospher column $(125 \times 3 \mathrm{~mm}, 5 \mu \mathrm{m}$, Merck $)$ at $25^{\circ} \mathrm{C}$. The mobile phases were: A-water acidified with $0.05 \%$ trifluoroacetic acid (TFA, Merck) and B-acetonitrile (Merck) acidified with $0.05 \%$ TFA (45:55), at a flow rate of $0.6 \mathrm{ml} / \mathrm{min}$. The detector parameters were as follows: excitation wavelength $470 \mathrm{~nm}$ and emission wavelength $530 \mathrm{~nm}$. ANTX standard (Tocris, Bioscience) was used for identification and quantitative determinations of the toxin. 
Statistical analysis

The differences in some morphological features of the lakes (depth and frequency of water-level manipulations) and physicochemical parameters of lake and canal waters were analysed using one-way analysis of variance (ANOVA). Redundancy analysis (RDA) was used to explore the relationships between the biomass of cyanobacteria and environmental factors. RDA for cyanobacterial biomass and different variants of microcystins also was performed but on log-normal transformed data. A Monte Carlo analysis with 499 permutations was used to determine the most important variables. The ordination analyses were performed using CANOCO 4.5 software for Windows (ter Braak \& Šmilauer, 2002).

\section{Results}

Environmental background

The morphological features and the physicochemical parameters of waters of the modified lakes are presented in Tables 1 and 2, respectively. Some of the environmental factors showed significant differences among the studied lakes: among morphological factors, it was depth $(F=197.05, \quad$ d.f. $=3$, $P<0.001)$ and the frequency of water-level manipulations (water re-filling pulse) $(F=5.00$ d.f. $=3$, $P=0.022$ ). The lakes were enriched periodically with high amounts of biogenic compounds from the canal water (Table 3). The waters entering Lakes Dratów, Krzczeń and Domaszne contained very similar concentrations and proportions of $\mathrm{N}-\mathrm{NH}_{4}, \mathrm{~N}-\mathrm{NO}_{3}$ (1:5) and $\mathrm{P}_{-} \mathrm{PO}_{4}$ (Table 3 ) and statistically important differences between the lakes were only observed for $\mathrm{N}-\mathrm{NH}_{4}(F=3.82$, d.f. $=3, P=0.025)$, the highest concentrations of which were introduced to Lake Białe S. Lakes Dratów and Krzczeń have volumes ca. twice higher than Lakes Domaszne and Białe S. and differ in terms of their man-made water management (Table 1; Fig. 2). In Lakes Dratów and Krzczeń, the average water amplitudes were $67 \mathrm{~cm}$ and $40 \mathrm{~cm}$, respectively. In Lake Domaszne, the average water amplitude was higher $(87 \mathrm{~cm})$, and there were irregular manipulations with water used for fish farming and field irrigation. Lake Białe S. is mainly used as a water reservoir for private fish farming. In both of the latter lakes, three to five water outputs and re-fillings per year were noted (Fig. 2). The water re-filling rates were very similar in the lakes during the period of water input (3.5-4.3\% of lake volume $\mathrm{day}^{-1}$, Table 1). In all the lakes (Table 2), the water was slightly alkaline ( $\mathrm{pH} 7.4-8.5)$, rich in nutrients, and of a similar temperature range $\left(16.3-18.6^{\circ} \mathrm{C}\right)$ during the study periods. The average $\mathrm{N}^{-N_{4}}$ concentration ranged from 0.085 to $0.168 \mathrm{mg}^{-1}$ in the following pattern: Lakes Białe S. $>$ Domaszne, Dratów, Krzczeń. The average $\mathrm{N}^{-\mathrm{NO}_{3}}$ concentration ranged from 0.057 to $0.225 \mathrm{mg} \mathrm{l}^{-1}$ and changed between the two years, whereas the $\mathrm{P}_{-} \mathrm{PO}_{4}$ concentrations were the lowest of the biogenic compounds and fluctuated in a narrower range of values $\left(0.024-0.082 \mathrm{mg} \mathrm{l}^{-1}\right)$ than nitrate and ammonium nitrogen. The ratio of dissolved inorganic nitrogen to dissolved inorganic phosphorus (DIN/DIP) was higher (15.4-27.5) in Lake Białe S. than in the other lakes; however, there were no statistically important differences between the lakes. Lower water transparency and a higher chl-a concentration in the water were, however, observed in Lakes Dratów and Krzczeń (0.23-0.38 m and 79.1-247.6 $\mu \mathrm{g}$ chl- $a 1^{-1}$, respectively) than in Lakes Domaszne and Białe S. (0.40-1.00 m and 29.8-120.5 $\mu \mathrm{g}$ chl- $a 1^{-1}$, respectively). The differences were statistically important in the case of water transparency $(F=17.90$, d.f. $=3, P<0.001)$, chl- $a(F=6.14$, d.f. $=2, \quad P=0.004), \quad$ TOC $(F=8.90, \quad$ d.f. $=3$, $P=0.001)$ and TSS $(F=6.22$, d.f. $=3, P=0.004)$.

Cyanobacteria community composition

In total, 24 potentially toxic cyanobacteria taxa were found over the study period in Lake Krzczeń, 20 in Lake Dratów, 19 in Lake Domaszne and 30 in Lake Białe S. The communities of potentially toxigenic cyanobacteria in Lakes Krzczeń and Dratów were the most similar (Jaccard index 0.68) and their taxonomic similarity was much higher in comparison with the smaller Lakes: Białe S. (0.52; 0.54) and Domaszne $(0.39 ; 0.44)$. Species diversity (Table 4$)$ of potentially toxic cyanobacteria (expressed as the ShannonWiener index) was lower in Lakes Dratów and Krzczeń than in Lakes Domaszne and Białe S., which were subjected to more frequent man-made water manipulations. The development of cyanobacterial biomass is presented in Fig. 3 and Table 4. Generally, in Lakes Dratów and Krzczeń, the biomass (max. 25.6 


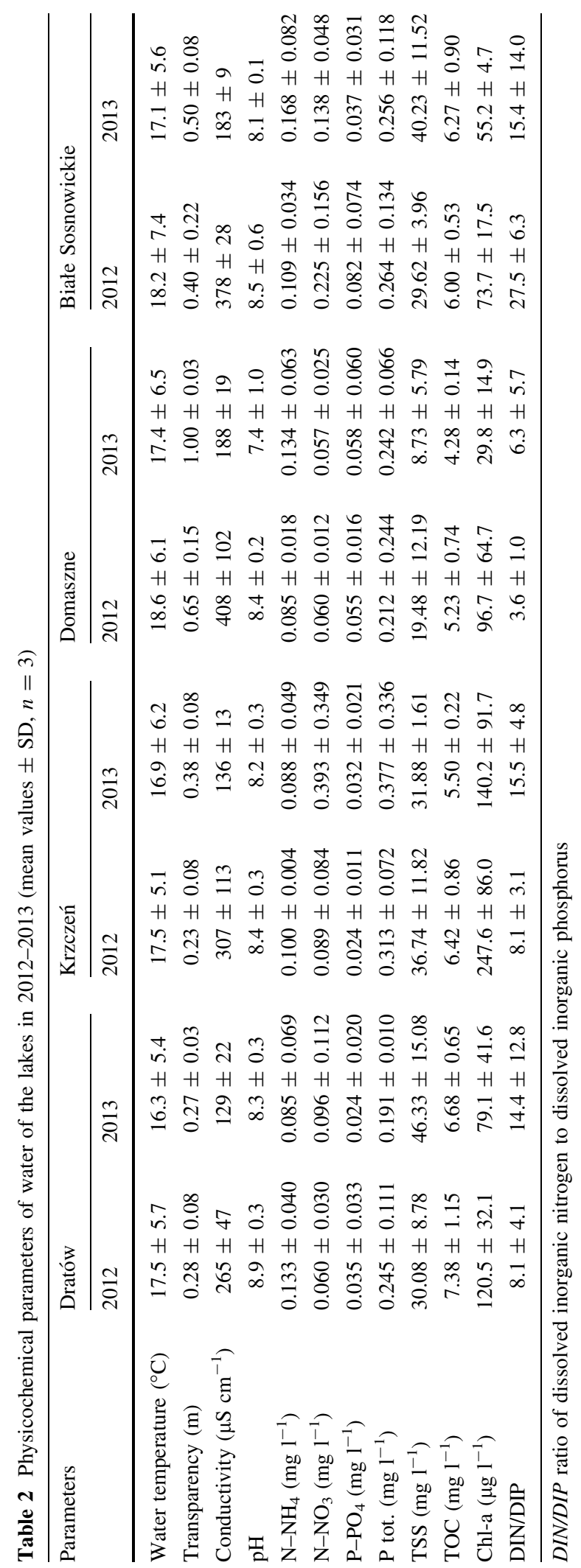


Table 3 Chemical characteristics of the canal waters introduced to the lakes (mean values for 2012-2013; $n=6$; and mean values for particular years, respectively-in parenthesis; $n=3$ )

\begin{tabular}{|c|c|c|c|c|}
\hline Parameters & Dratów & Krzczeń & Domaszne & Białe Sosnowickie \\
\hline $\mathrm{pH}$ & $\begin{array}{l}8.0 \\
(8.2 ; 7.8)\end{array}$ & $\begin{array}{l}8.0 \\
(8.2 ; 7.8)\end{array}$ & $\begin{array}{l}8.2 \\
(8.5 ; 7.9)\end{array}$ & $\begin{array}{l}7.3 \\
(7.4 ; 7.2)\end{array}$ \\
\hline Conductivity $\left(\mu \mathrm{S} \mathrm{cm}^{-1}\right)$ & $\begin{array}{l}413 \\
(533 ; 292)\end{array}$ & $\begin{array}{l}413 \\
(532 ; 294)\end{array}$ & $\begin{array}{l}417 \\
(538 ; 296)\end{array}$ & $\begin{array}{l}358 \\
(458 ; 257)\end{array}$ \\
\hline $\mathrm{N}-\mathrm{NH}_{4}\left(\mathrm{mg} \mathrm{l}^{-1}\right)$ & $\begin{array}{l}0.128 \\
(0.111 ; 0.144)\end{array}$ & $\begin{array}{l}0.123 \\
(0.108 ; 0.138)\end{array}$ & $\begin{array}{l}0.109 \\
(0.105 ; 0.112)\end{array}$ & $\begin{array}{l}0.356 \\
(0.423 ; 0.289)\end{array}$ \\
\hline $\mathrm{N}-\mathrm{NO}_{3}\left(\mathrm{mg} \mathrm{l}^{-1}\right)$ & $\begin{array}{l}0.624 \\
(0.624 ; 0.625)\end{array}$ & $\begin{array}{l}0.578 \\
(0.550 ; 0.606)\end{array}$ & $\begin{array}{l}0.642 \\
(0.652 ; 0.632)\end{array}$ & $\begin{array}{l}0.324 \\
(0.153 ; 0.495)\end{array}$ \\
\hline $\mathrm{P}-\mathrm{PO}_{4}\left(\mathrm{mg} \mathrm{l}^{-1}\right)$ & $\begin{array}{l}0.122 \\
(0.130 ; 0.114)\end{array}$ & $\begin{array}{l}0.111 \\
(0.067 ; 0.155)\end{array}$ & $\begin{array}{l}0.116 \\
(0.073 ; 0.160)\end{array}$ & $\begin{array}{l}0.065 \\
(0.055 ; 0.074)\end{array}$ \\
\hline $\mathrm{P}$ tot. $\left(\mathrm{mg} \mathrm{l}^{-1}\right)$ & $\begin{array}{l}0.199 \\
(0.168 ; 0.230)\end{array}$ & $\begin{array}{l}0.196 \\
(0.160 ; 0.231)\end{array}$ & $\begin{array}{l}0.211 \\
(0.185 ; 0.236)\end{array}$ & $\begin{array}{l}0.213 \\
(0.0 .282 ; 0.143)\end{array}$ \\
\hline DIN/DIP & $\begin{array}{l}6.9 \\
(6.4 ; 7.5)\end{array}$ & $\begin{array}{l}8.1 \\
(10.9 ; 5.4)\end{array}$ & $\begin{array}{l}8.2 \\
(10.5 ; 6.0)\end{array}$ & $\begin{array}{l}15.1 \\
(10.8 ; 19.3)\end{array}$ \\
\hline
\end{tabular}

DIN/DIP ratio of dissolved inorganic nitrogen to dissolved inorganic phosphorus

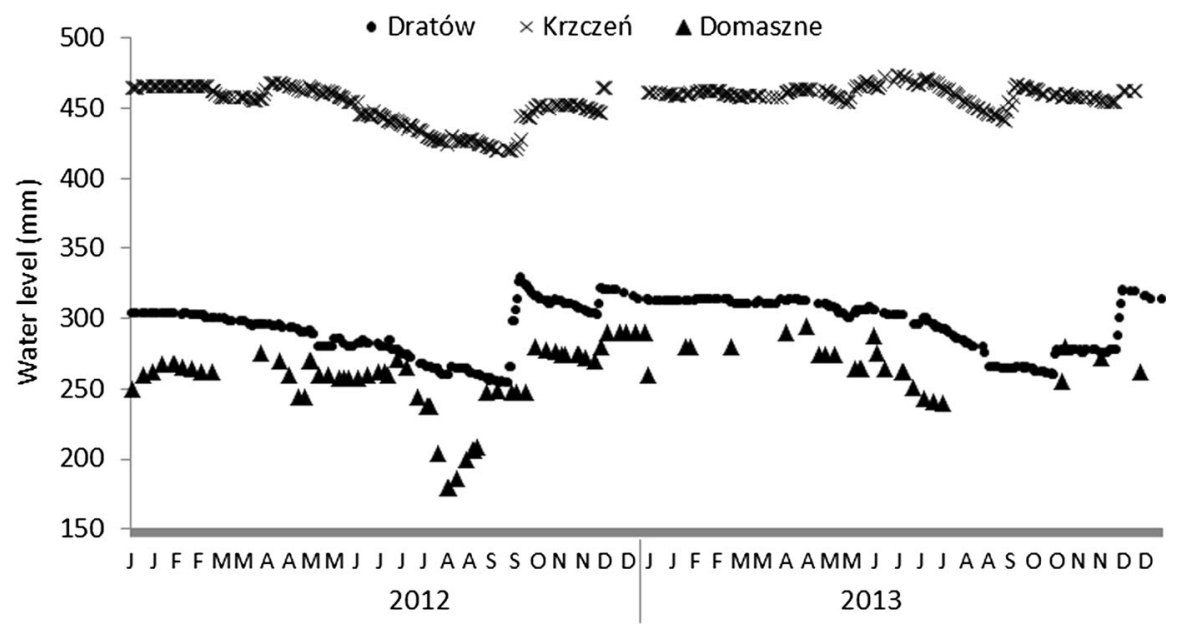

Fig. 2 Annual water-level fluctuations in Lakes Dratów, Krzczeń and Domaszne in 2012-2013

and $23.9 \mathrm{mg} \mathrm{l}^{-1}$, respectively) was higher than in Lakes Domaszne (max. $16.8 \mathrm{mg}^{-1}$ ) and Białe S. (max. $10.6 \mathrm{mg} \mathrm{l}^{-1}$ ). In the larger lakes, with one water re-filling event per year, filamentous Aphanizomenon spp. (in Lake Dratów), Aphanizomenon spp. and Dolichospermum spp. (in Lake Krzczeń) predominated in spring, whereas in summer and autumn, the coccoid Microcystis spp. were dominant (Table 4). In the smaller lakes, with more frequent water manipulations, the qualitative structure of the cyanobacterial biomass was more diverse and consisted of different Nostocales, Oscillatoriales and/or Chroococcales taxa, depending on the year and season (Fig. 3; Table 4). In Lakes Krzczeń and Dratów, the structure of cyanobacterial communities forming a very high biomass was similar in both years, especially in summer and autumn. Apparent differences in the taxonomic structure were observed in 2012 and 2013 in the other two lakes. In Lake Domaszne, A. flos-aque, M. aeruginosa and Planktothrix agardhii predominated in 2012; however, in 2013 only Oscillatoriales occurred in higher amounts. In Lake Białe S., the predominance of Planktolyngbya limnetica, Cuspidothrix issatschenkoi, M. wesenbergii and Dolichospermum spp. was 
Table 4 Annual mean biomass $\left(\mathrm{mg}^{-1}\right)$ of potentially toxic cyanobacteria (dominant genera given in bold), total number of taxa and diversity (mean Shannon-Wiener index)

\begin{tabular}{|c|c|c|c|c|c|c|c|c|}
\hline \multirow[t]{2}{*}{ Cyanobacteria } & \multicolumn{2}{|c|}{ Dratów } & \multicolumn{2}{|c|}{ Krzczeń } & \multicolumn{2}{|c|}{ Domaszne } & \multicolumn{2}{|c|}{ Białe Sosnowickie } \\
\hline & 2012 & 2013 & 2012 & 2013 & 2012 & 2013 & 2012 & 2013 \\
\hline Microcystis spp. & $6.33^{\mathrm{a}}$ & $10.97^{\mathrm{a}}$ & $13.40^{\mathrm{b}}$ & $6.46^{\mathrm{b}}$ & $2.98^{c}$ & 0.10 & 0.38 & $0.74^{d}$ \\
\hline Woronichinia spp. & 0.12 & 0.33 & 0.01 & 0.37 & 0.35 & 0.003 & 0.02 & 0.04 \\
\hline Dolichospermum spp. & 0.02 & 0.36 & $1.74^{\mathrm{e}}$ & $2.15^{\mathrm{f}}$ & 0.47 & 0.36 & 0.05 & $4.24^{\mathrm{g}}$ \\
\hline Aphanizomenon spp. (with Cuspidothrix spp.) & $4.12^{\mathrm{h}}$ & $4.93^{\mathrm{h}}$ & $\mathbf{5 . 4 7 ^ { \mathrm { i } }}$ & 0.001 & $3.22^{\mathrm{h}}$ & 0.16 & 0.51 & $1.37^{\mathrm{h}}$ \\
\hline Planktolyngbya spp. & $1.93^{\mathrm{j}}$ & 0.36 & 0.21 & 0.32 & $0.76^{\mathrm{j}}$ & $0.77^{\mathrm{j}}$ & 0.57 & $0.71^{\mathrm{k}}$ \\
\hline Planktothrix agardhii & 0.22 & n.f. & 0.05 & n.f. & 0.92 & 0.17 & 0.03 & n.f. \\
\hline Limnothrix spp. & 0.01 & n.f. & 0.01 & n.f. & $1.03^{1}$ & 0.34 & 0.001 & 0.05 \\
\hline Others & n.f. & 0.08 & 0.11 & 0.01 & 0.04 & 0.05 & 0.09 & 0.61 \\
\hline Total biomass & 12.75 & 17.02 & 21.00 & 9.30 & 9.76 & 1.95 & 1.65 & 7.76 \\
\hline Total number of cyanobacterial taxa & 20 & & 24 & & 19 & & 30 & \\
\hline Diversity index & 0.425 & & 0.435 & & 0.565 & & 0.765 & \\
\hline
\end{tabular}

The dominant species: ${ }^{\mathrm{a}} M$. viridis $=$ M. wesenbergii $>$ M. aeruginosa

${ }^{\mathrm{b}} M$. wesenbergii $>$ M. viridis $=M$. aeruginosa

c $M$. aeruginosa $>M$. viridis $>M$. wesenbergii

d $M$. wesenbergii $>M$. aeruginosa $>M$. viridis

e D. crassum $>$ D. flos-aquae

${ }^{f}$ D. flos-aquae $>$ D. crassum

g D. circinale $>$ D. crassum $>$ D. planctonicum

h Aph. flos-aquae > Aph. gracile

${ }^{\mathrm{i}}$ Aph. flos-aquae

${ }^{\mathrm{j}}$ P. limnetica

${ }^{\mathrm{k}} P$. limnetica $>P$. contorta

${ }^{1}$ L. redekei

$n . f$. not found

noted in 2012, and their biomass increased considerably in the following year (especially that of $D$. circinale, D. crassum and D. planctonicum). One invasive species that is new to Eastern Poland, Cylindrospermopsis raciborski, was found in Lake Białe S. in autumn 2013 (at a low biomass level of $0.002 \mathrm{mg} \mathrm{l}^{-1}$ ).

The RDA analysis (Fig. 4) showed that all the variables accounted for $63 \%$ of the total variance in the composition of cyanobacterial communities. However, the variable that most significantly explained the variance in the communities was the frequency of the water-level fluctuations $(\lambda=0.23$; $F=6.52 ; P=0.008$ ). More frequent water-level manipulations supported the development of different Oscillatoriales but limited growth of Chroococcales (mainly Microcystis). Lake depth was most important for Microcystis, $\mathrm{pH}$ was a key factor for
Aphanizomenon development, however, higher water temperature was essential for both species.

\section{Cyanotoxins}

Microcystins (MCs) were detected in all lakes studied (Fig. 5). The total concentrations of intracellular MCs were much higher in Lakes Dratów and Krzczeń (with a higher cyanobacterial biomass) than in Lakes Domaszne and Białe S. The same MC variants, i.e. MC-LF, -RR, -LR, predominated in Lakes Dratów and Krzczen in both years; however, only MC-LF was detected at a very high concentration $\left(10.9 \mathrm{mg} \mathrm{l}^{-1}\right)$ in the surface scum formed by $M$. wesenbergii (97\% of the biomass) in Lake Krzczeń in 2012. In 2013, when the scum was formed by a mixture of Dolichospermum spp. and Microcystis spp., four MC variants were detected with MC-LF (75\% of the total MC 

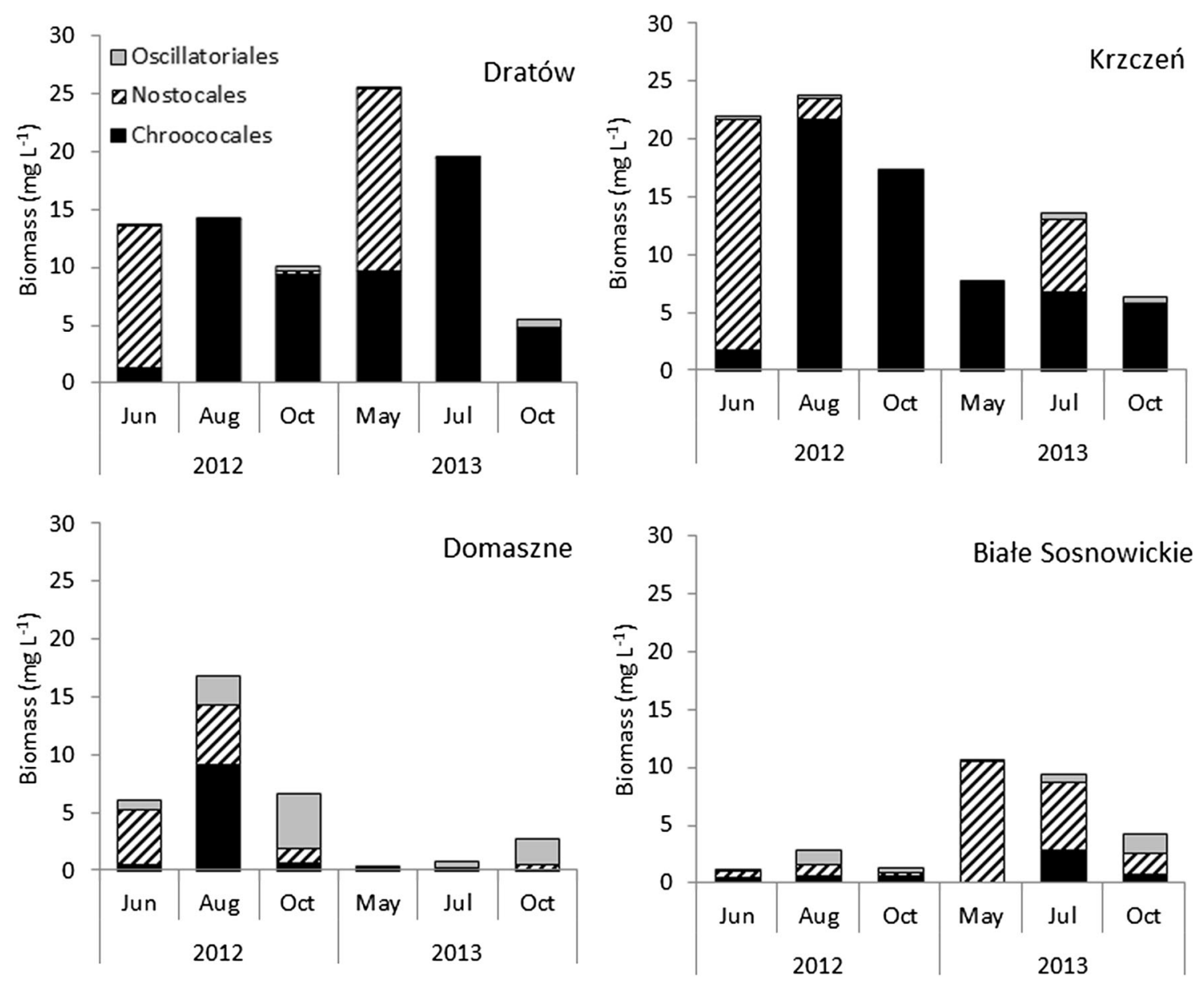

Fig. 3 Seasonal changes in the biomass of toxigenic cyanobacteria in the lakes (2012-2013)

concentration) $>-\mathrm{RR}>-\mathrm{LY}>-\mathrm{LA}$. The total $\mathrm{MC}$ concentration in Lake Dratów ranged from 0.23 to $24.6 \mu \mathrm{g}^{-1}$; in Lake Krzczeń this was from 1.12 to $25.3 \mu \mathrm{g} \mathrm{l}^{-1}$, whereas in Lakes Domaszne and Białe S. the total MC concentrations in water were lower and ranged from 0.90 to $2.99 \mu \mathrm{g}^{-1}$ and from 0.52 to $5.06 \mu \mathrm{g}^{-1}$, respectively. In all lakes, the MC concentrations were generally higher in spring and summer than in autumn. Four to seven MC variants were detected, with the highest variability between the two years in Lake Domaszne. Intracellular ANTX was detected only in Lake Krzczeń in spring and autumn (0.59 and $0.17 \mu \mathrm{g} \mathrm{l}^{-1}$, respectively; data not shown).

RDA analysis (Fig. 6) indicated the significance $(\lambda=0.53 ; F=24.85 ; P=0.002)$ of Microcystis spp. in the production of the dominant MC variants (MCLF, -LR and -RR). All the variables explained $59 \%$ of the total variance. Other cyanobacteria taxa seemed to have contributed to the production of other $\mathrm{MC}$ variants (MC-LA, -LY,-LW,-WR), which were found at much lower concentrations.

\section{Discussion}

The study revealed that in nutrient-rich water bodies, a higher frequency of water-level manipulations, which increased also flushing rate, was beneficial due to decrease cyanobacterial blooms and cyanotoxin production. Both a decrease in toxigenic cyanobacterial biomass and increase in species diversity were found. As reported previously (Lindenschmidt \& Chorus, 1998; Padisák, et al., 1999; Weithoff et al., 2001; Geraldes \& Boavida, 2005; Naselli-Flores \& Barone, 2005; Haldna et al., 2008) disturbances in the physical environment (stratification, light availability, water 


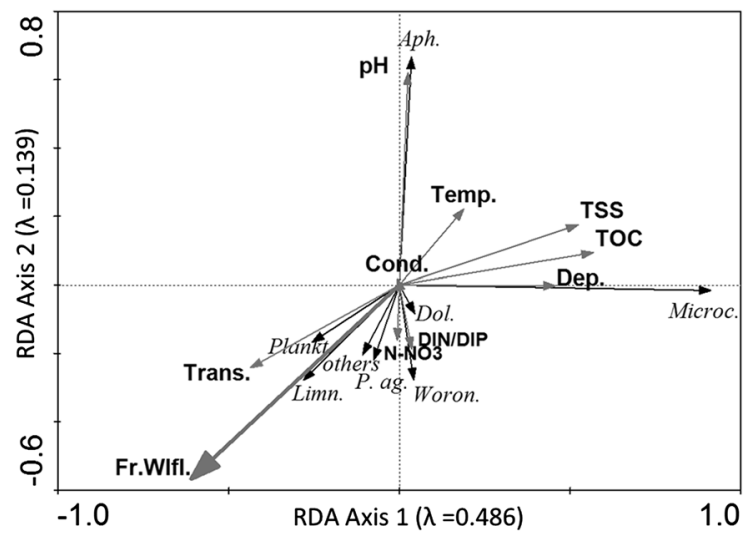

Fig. 4 Redundancy analysis (RDA) showing environmental variables and cyanobacterial biomass. Bolded arrow indicate frequency of water-level fluctuations as significant variable based on Monte Carlo permutation test $(P=0.008)$. Fr.Wlfl. frequency of water-level fluctuations, Dep. depth, Trans. water transparency, Temp. water temperature, Cond . conductivity, $\mathrm{N}-$ $\mathrm{NO}_{3}$ nitrate nitrogen, DIN/DIP ratio of dissolved inorganic nitrogen to dissolved inorganic phosphorus, TSS total suspended solids, TOC total organic carbon, Aph, Aphanizomenon spp. including Cuspidothrix spp., Dol, Dolichospermum spp.; Limn, Limnothrix spp., Microc, Microcystis spp.; P. ag., Planktothrix agardhii; Plankt, Planktolyngbya spp., Woron, Woronichinia spp. (mainly W. naegeliana); others Anabaena cf. oscillarioides, Cyl. raciborski, Gomphosphaeria sp., Snowella spp.

mixing, flushing rate) and water chemistry affect phytoplankton in terms of biomass, species composition, diversity and succession of dominance both in natural and artificial water bodies. In our study, the frequency of anthropogenic water-level fluctuations and depth of the lakes were the main factors differentiating the lakes supplied with nutrient-rich waters from the same canal. Frequent water manipulations increased flushing rate considerably and must have created disturbances in a stability of water column and water temperature. As reported by Padisák, et al. (1999) a decrease in cyanobacteria biomass to low levels in a lake with continuous high flushing was a consequence of intolerance of cyanobacteria to sudden hydrological disturbances caused by high frequency of flushing pulses. As indicated by the RDA analysis in this study, the frequency of water-level manipulations was a statistically important factor influencing also the composition of cyanobacterial communities. We found that a single water-level regulation per year (only re-filling event), carried out in autumn, did not cause any essential change in the development of dominant toxin-producing cyanobacteria over the following 2 years: mainly Microcystis spp. (Chroococcales) and Aphanizomenon flos-aquae or Dolichospermum spp. (Nostocales). Their biomass remained constantly high, with a dominance of Microcystis spp. In deeper Lakes Dratów and Krzczeń, of larger volume, the single water re-filling pulse in autumn did not influence the species diversity of cyanobacteria communities. Species similarity of these lakes was high (Jaccard index $=0.68$ ), concomitant with the lowest species diversity. As reported by Lindenschmidt \& Chorus (1998) Microcystis, Aphanizomenon and Dolichospermum are species which prefer prolonged stable conditions in water column. Interestingly, the highest species diversity was found in Lake Białe S., where species similarity to other lakes was intermediate. This may suggest a transient, non-stable state of the cyanobacterial community which can change along with a change in abiotic factors, such as nutrient concentrations, their proportions and water mixing. A similar relationship between phytoplankton species similarity and diversity had been found during a three-year study (Weithoff et al., 2001) of Lake Falkensee (Germany). In Lake Białe S., which received canal waters (indirectly via a ditch surrounding the lake) with a lower concentration of $\mathrm{P}_{-} \mathrm{PO}_{4}$, a higher concentration of $\mathrm{N}-\mathrm{NH}_{4}$ and a higher average DIN:DIP ratio than in the other three lakes, the total cyanobacterial biomass was lower, but the total species richness of cyanobacteria found over the two-year study period was the highest (30 taxa). Similar observations have been reported for a shallow dam reservoir in Poland (Pawlik-Skowronska et al., 2013). The most pronounced example of the essential role of the high frequency of water manipulations (causing increased flushing) in the development of cyanobacteria is Lake Domaszne, which received waters with the same chemical composition directly from the canal, but at a much higher frequency (3-5) each year than Lakes Dratów and Krzczeń. In Lake Domaszne, cyanobacterial species diversity was higher (Shannon-Wiener index 0.6-0.7) and species similarity to the larger lakes was the lowest (Jaccard index 0.39-044). Also, the biomass of dominant taxa of potentially toxic cyanobacteria (Microcystis spp., Aph. flos-aquae, Dolichospermum spp.) was severalfold lower, and consequently, concentrations of cellbound microcystins (MCs) were lower than in Lakes Dratów and Krzczeń, but with higher MC-variant richness. The dominance of Microcystis in the biomass suggested that water mixing and turbulence in the 

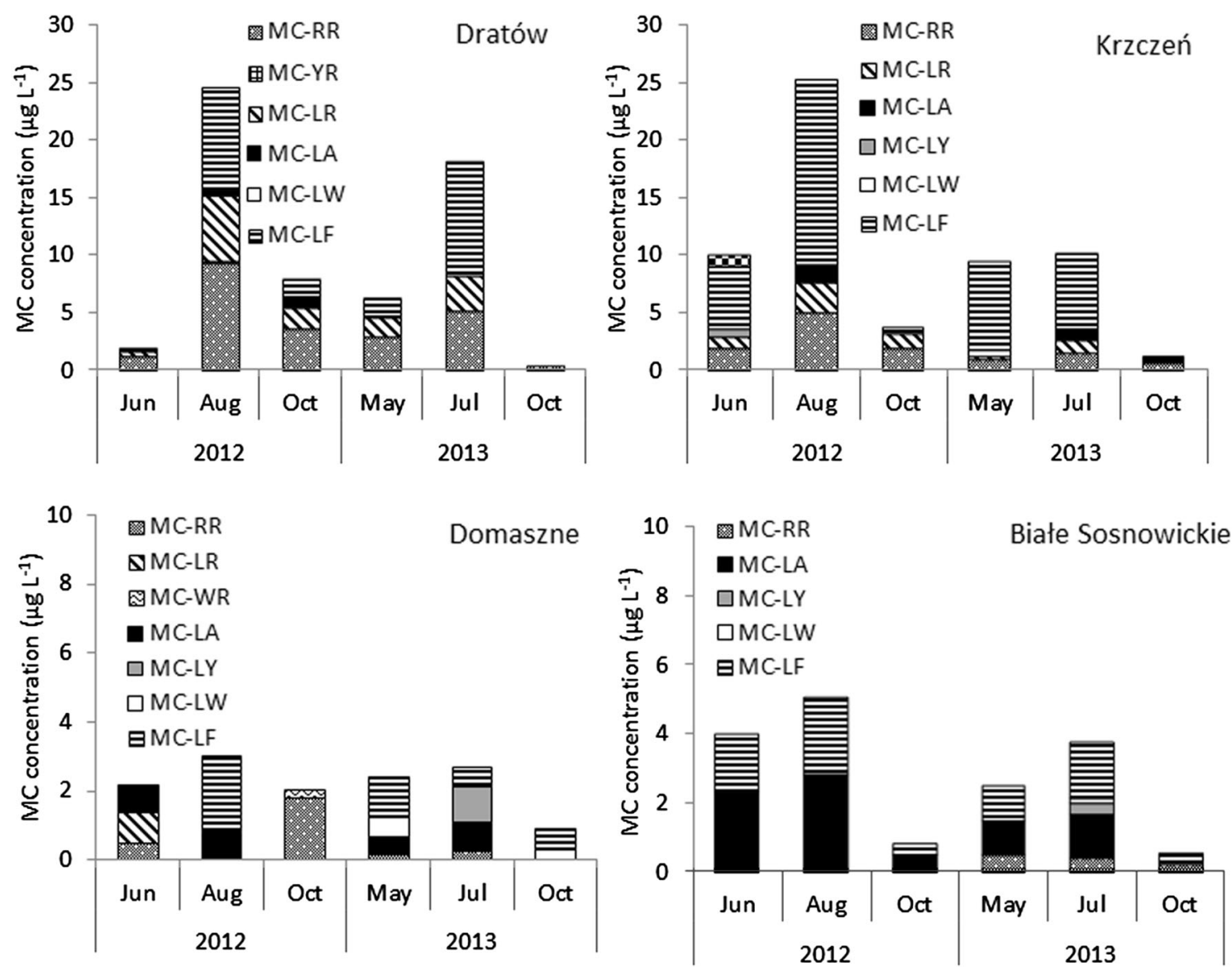

Fig. 5 Seasonal variability and concentrations of particular microcystin variants detected in the lakes in 2012-2013

"regulated" Lakes Dratów and Krzczeń with a single water re-filling event had low impact, but in Lake Domaszne, in which P. agardhii and other Oscillatoriales also developed periodically in noticeable amounts, the water turbulence resulting from several water outputs and re-filling events per year must have been stronger. P. agardhii and Limnothrix spp. prefer turbulent conditions (Scheffer et al., 1997; Lindenschmidt \& Chorus, 1998) and can form toxigenic perennial blooms in shallow, flow-through lakes and dam reservoirs (Grabowska et al., 2014; Toporowska \& Pawlik-Skowronska, 2014). As reported by Carvalho et al. (2011) and Romo et al. (2013), longer water residence time increased total cyanobacteria biomass, like in the case of Microcystis populations and MC concentrations in the lakes studied, with the low frequency of water-level changes and small flushing. Large, buoyant colonies of Microcystis spp. take advantage of stable water column and as found in a Spanish lake (Romo et al., 2013) both the abundance and biovolume of Microcystis aeruginosa negatively correlated with rate of water flushing. Interestingly, in the lakes with the single water-level regulation microcystins -LF, -RR and -LR were the dominant variants produced by a mixture of three species of Microcystis and $M$. wesenbergii seemed to be the main producer of MC-LF. MC production by this species was rarely reported: MC-LA was suggested by Monchamp et al. (2014), while some European and Chinese strains did not produce MC at all (ViaOrdorika et al., 2004; Xu et al., 2008). The variability of the production of MC variants presented in this work is characteristic not only for Microcystis spp. (Via-Ordorika et al., 2004) but also for other species, for example D. planctonicum and P. agardhii (PawlikSkowronska et al., 2013; Grabowska et al., 2014; Monchamp et al., 2014). Both the number and the type of MC variants (MC profile) change over time and are 


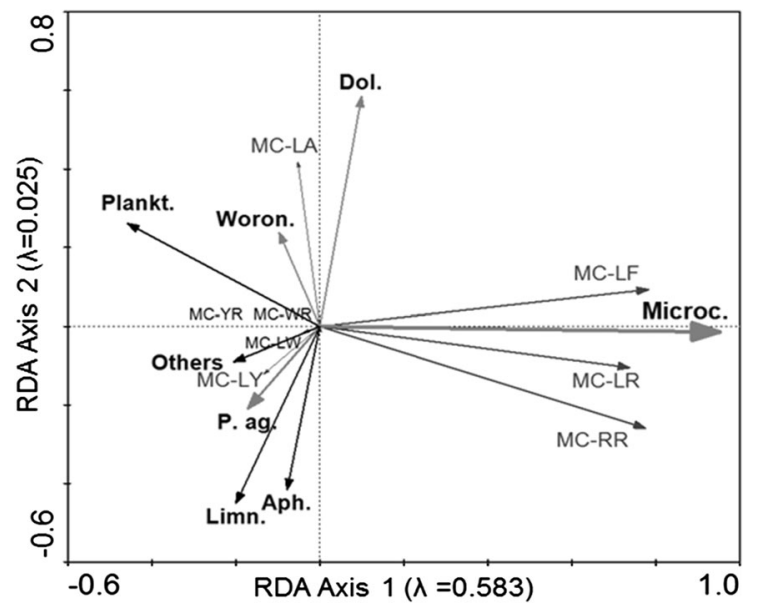

Fig. 6 Redundancy analysis (RDA) showing significance of Microcystis spp. in the production of the dominant microcystin variants MC-LF, LR, RR: Monte Carlo permutation test ( $\lambda=0.53 ; F=24.85 ; P=0.002)$. Aph, Aphanizomenon spp. including Cuspidothrix spp., Dol. Dolichospermum spp., Limn. Limnothrix spp., Microc, Microcystis spp., P. ag, Planktothrix agardhii; Plankt, Planktolyngbya spp., Woron, Woronichinia spp. (mainly W. naegeliana); others Anabaena cf. oscillarioides, Cyl. raciborski, Gomphosphaeria sp., Snowella spp.

dependent on the species richness and biomass of the cyanobacteria community (Pawlik-Skowronska et al., 2013). The occurrence of higher number of MC variants of different toxicity (Tonk et al., 2005) but in low concentrations was less hazardous and therefore more advantageous for biocenoses of Lakes Domaszne and Białe S. than for other lakes. The maximum total MC concentrations in the lakes with single water-level regulation (Lakes Dratów and Krzczeń) were similar to the MC concentrations (22-23 $\mathrm{g}^{-1}$ ) reported in the $P$. agardhii dominated dam reservoir in northeast of Poland (Grabowska et al., 2014) and in a dam reservoir in Eastern Poland with mixed Microcystis/Dolichospermum/P. agardhii blooms (Pawlik-Skowronska et al., 2013). However, even higher MC concentrations were reported in hypertrophic lakes across Europe (Table 5). ANTX concentration (detected only in Lake Krzczeń) was higher than those reported by Ballot et al. (2010) in the German Lake Stolpsee, in which $C$. issatschenkoi developed (found also in low density in Lake Krzczeń), but lower than in a hypertrophic dam reservoir in Poland (up to $120 \mu \mathrm{g} \mathrm{l}{ }^{-1}$, PawlikSkowronska et al., 2004), where ANTX positively correlated with the biomass of Dolichospermum spp. (former Anabaena spp.), but not with Aph. flos-aquae. This could explain why ANTX was not detected in Lake Dratów. The results may suggest that the intensity of cyanobacterial blooms and cyanotoxin

Table 5 Examples of maximum concentrations of intracellular microcystins detected in reservoirs and lakes in Europe during mass development of particular cyanobacteria

\begin{tabular}{|c|c|c|c|c|}
\hline Dominant cyanobacteria & 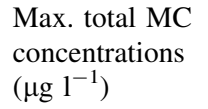 & Reservoir/lake name & Location & Literature \\
\hline $\begin{array}{l}\text { Microcystis sp., } \\
\text { Dolichospermum sp. }\end{array}$ & 4.6 & Skalka Reservoir & Czech Republic & Jančula et al. (2014) \\
\hline M. aeruginosa, D. lemmermannii & 0.4 & Lake Vargsundet & Finland & Lindholm et al. (2003) \\
\hline M. aeruginosa, $P$. agardhii & 5.7 & Lake Prästträsket & & \\
\hline P. agardhii & 5.5 & Lake Viry-Châtillon & France & Briand et al. (2002) \\
\hline P. rubescens & 17.0 & Lake Occhito & Italy & Salmaso et al. (2014) \\
\hline Cylindrospermopsis raciborski & 15.0 & Kerkini Reservoir & Greece & Gkelis \& Zaoutsos (2014) \\
\hline Microcystis spp. & 99.0 & Lake Pamvotis & & \\
\hline P. agardhii & 23.1 & Siemianowka Reservoir & Poland & Grabowska et al. (2014) \\
\hline $\begin{array}{l}\text { Microcystis spp. } \\
\text { Dolichospermum spp. } \\
\text { P. agardhii }\end{array}$ & 22.2 & Zemborzycki Reservoir & & $\begin{array}{l}\text { Pawlik-Skowronska } \\
\text { et al. (2013) }\end{array}$ \\
\hline P. agardhii & 6.6 & Lake Jagodne & & Mankiewicz et al. (2005) \\
\hline P. agardhii & 123.6 & Lake Syczyńskie & & $\begin{array}{l}\text { Toporowska \& } \\
\text { Pawlik-Skowronska (2014) }\end{array}$ \\
\hline M. aeruginosa & 120.5 & Lake Albufera & Spain & Romo et al. (2013) \\
\hline
\end{tabular}


production in the strongly eutrophicated modified lakes depend considerably on the frequency of manmade water management which modulates flushing rate. This is the first report on a field study concerning variability in cyanobacterial species richness, diversity, cyanotoxin production and MC variants in several managed lakes connected to one canal system and subjected to water-level regulations. The results obtained here strongly suggest that a higher frequency of water-level manipulations that increases flushing rate may limit cyanobacterial blooms and cause a consequent decrease in cyanotoxin production. Physical disturbance of stratification concomitant with an increase in the intensity of water mixing seem to be the main mechanisms of the observed changes in the quantitative and qualitative structure of cyanobacterial communities. This may support the intermediate disturbance hypothesis of Padisák et al. (1993).

\section{Conclusions}

Different consequences of water management in hypertrophic "regulated" lakes were observed: (i) more stable cyanobacterial blooms (of lower species diversity, high biomass, and high cyanotoxin concentrations) occurred in the larger lakes with smaller and less frequent water-level fluctuations; (ii) unstable cyanobacterial blooms of higher species diversity, lower biomass and lower cyanotoxin production were found in the smaller lakes with more frequent man-made interventions that increased flushing rate. In nutrient-rich reservoirs with water management, the increased flushing rate can efficiently limit the development of toxigenic Chroococcales (mainly Microcystis) and support different species of Oscillatoriales. Such a change can be beneficial due to total reduction in mass development of cyanotoxin producers.

Acknowledgments Authors thank to $\mathrm{M}$. Solis $(\mathrm{PhD})$ for information on water management in lakes and to anonymous reviewers for valuable remarks and comments.

Open Access This article is distributed under the terms of the Creative Commons Attribution 4.0 International License (http:// creativecommons.org/licenses/by/4.0/), which permits unrestricted use, distribution, and reproduction in any medium, provided you give appropriate credit to the original author(s) and the source, provide a link to the Creative Commons license, and indicate if changes were made.

\section{References}

Adamczuk, M., T. Mieczan, D. Nawrot \& J. Rechulicz, 2015. Indirect effect of environmental factors on interactions between microbial and classical food webs in freshwater ecosystems. Annales de Limnologie-International Journal of Limnology 51(1): 49-58.

Ballot, A., J. Fastner, M. Lentz \& C. Wiedner, 2010. First report of anatoxin-a-producing cyanobacterium Aphanizomenon issatschenkoi in northeastern Germany. Toxicon 56(6): 964-971.

Beklioglu, M., S. Romo, I. Kagalou, X. Quintana \& E. Becares, 2007. State of the art in the functioning of shallow Mediterranean lakes: workshop conclusions. Hydrobiologia 584(1): 317-326.

Bond, N. R., P. S. Lake \& A. H. Arthington, 2008. The impacts of drought on freshwater ecosystems: an Australian perspective. Hydrobiologia 600(1): 3-16.

Briand, J. F., C. Robillot, C. Quiblier-Lloberas \& C. Bernard, 2002. A perennial bloom of Planktothrix agardhii (Cyanobacteria) in a shallow eutrophic French lake: limnological and microcystin production studies. Archiv für Hydrobiologie 153(4): 605-622.

Carvalho, L., C. A. Miller, E. M. Scott, G. A. Codd, P. S. Davies \& A. N. Tyler, 2011. Cyanobacterial blooms: statistical models describing risk factors for national-scale lake assessment and lake management. Science of the Total Environment 409: 5353-5358.

Codd, G., L. F. Morrison \& J. S. Metcalf, 2005. Cyanobacterial toxins: risk management for health protection. Toxicology and Applied Pharmacology 203(3): 264-272.

Coops, H. \& S. H. Hosper, 2002. Water-level management as a tool for the restoration of shallow lakes in the Netherlands. Lake and Reservoir Management 18(4): 293-298.

Coops, H., M. Beklioglu \& L. Crisman, 2003. The role of waterlevel fluctuations in shallow lake ecosystems - workshop conclusions. Hydrobiologia 506(1): 23-27.

Dawidek, J., S. Sobolewski \& M. Turczyński, 2004. Transformations of catchment-areas of lakes converted into storage reservoirs in the Wieprz-Krzna Canal system. Limnological Review 4: 67-74.

Elliott, A., 2010. The seasonal sensitivity of Cyanobacteria and other phytoplankton to changes in flushing rate and water temperature. Global Change Biology 16(2): 864-876.

Freitas, M., J. Azevedo, E. Pinto, J. Neves, A. Campos \& V. Vasconcelos, 2015. Effects of microcystin-LR, cylindrospermopsin and a microcystin-LR/cylindrospermopsin mixture on growth, oxidative stress and mineral content in lettuce plants (Lactuca sativa L.). Ecotoxicology and Environmental Safety 116: 59-67.

Furey, A., J. Crowley, B. Hamilton, M. Lehane \& K. J. James, 2005. Strategies to avoid the mis-identyfication of anatoxin-a using mass spectrometry in the forensic investigation of acute neurotoxic poisoning. Journal of Chromatography 1082: 91-97.

Geraldes, A. M. \& M. J. Boavida, 2005. Seasonal water level fluctuations: implications for reservoir limnology and management. Lakes \& Reservoirs: Research and Management 10(1): 59-69. 
Gkelis, S. \& N. Zaoutsos, 2014. Cyanotoxin occurrence and potentially toxin producing cyanobacteria in freshwaters of Greece: a multi-disciplinary approach. Toxicon 78: 1-9.

Grabowska, M., J. Kobos, A. Toruńska-Sitarz \& H. MazurMarzec, 2014. Non-ribosomal peptides produced by Planktothrix agardhii from Siemianówka Dam Reservoir SDR (northeast Poland). Archives of Microbiology 196(10): 697-707.

Haldna, M., A. Milius, R. Laugaste \& K. Kangur, 2008. Nutrients and phytoplankton in Lake Peipsi during two periods that differed in water level and temperature. Hydrobiologia 599(1): 3-11.

Hermanowicz, W., W. Dożańska, J. Dojlido \& B. Koziorowski, 1976. Physical-chemical studies of water and wastes. Arkady, Warsaw. (in Polish).

Hillebrand, H., C.-D. Dürselen, D. Kirschtel, U. Pollingher \& T. Zohary, 1999. Biovolume calculation for pelagic and benthic microalgae. Journal of Phycology 35(2): 403-424.

Jaccard, P., 1912. The distribution of the flora in the alpine zone. New Phytologist 11(2): 37-50.

James, K. J., A. Furey, I. R. Sherlock, M. A. Stack, M. Twohing, F. B. Caudwell \& O. M. Skulberg, 1998. Sensitive determination of anatoxin-a, homoanatoxin-a and their degradation products by liquid chromatography with fluorometric detection. Journal of Chromatography A. 798: 147-157.

Jančula, D., L. Straková, J. Sadílek, B. Maršálek \& P. Babica, 2014. Survey of cyanobacterial toxins in Czech water reservoirs - the first observation of neurotoxic saxitoxins. Environmental Science and Pollution Research 21(13): 8006-8015.

Kobos, J., A. Błaszczyk, N. Hohlfeld, A. Toruńska-Sitarz, A. Krakowiak, A. Hebel, K. Sutryk, M. Grabowska, M. Toporowska, M. Kokociński, B. Messyasz, A. Rybak, A. Napiórkowska-Krzebietke, L. Nawrocka, A. Pełechata, A. Budzyńska, P. Zagajewski \& H. Mazur-Marzec, 2013. Cyanobacteria and cyanotoxins in Polish freshwater bodies. Oceanological and Hydrobiological Studies 42(4): $358-378$.

Komárek, J. \& K. Anagnostidis, 1999, 2000. Chroococcales T 1. In Ettl, H., G. Gärtner, J. Gerloff, H. Heyning \& D. Mollenhauer (eds), Süßwasserflora von Mitteleuropa. Spektrum Akademischer Verlag, GmbH, Heidelberg.

Komárek, J. \& K. Anagnostidis, 2005. Oscillatoriales. T 2. In H. Ettl, G. Gärtner, J. Gerloff, H. Heyning \& D. Mollenhauer (eds), Süßwasserflora von Mitteleuropa. Spektrum Akademischer Verlag, München.

Komárek, J., 2013. Cyanoprokaryota 3: Heterocytous Genera. In Budel, B., G. Gartner, L. Krienitz \& M. Schagerl (eds), Süßwasserflora von Mitteleuropa, 19/3, Spektrum Akademischer Verlag, München.

Lindenschmidt, K.-E. \& I. Chorus, 1998. The effects of water column mixing on phytoplankton succession, diversity and similarity. Journal of Plankton Research 20(10): 1927-1951.

Leira, M. \& M. Cantonati, 2008. Effects of water-level fluctuations on lakes: an annotated bibliography. Hydrobiologia 613(1): 171-184.

Lindholm, T., P. Vesterkvist, L. Spoof, C. Lundberg-Niinistö \& J. Meriluoto, 2003. Microcystin occurrence in lakes in Åland. SW Finland. Hydrobiologia 505(1): 129-138.
Mankiewicz, J., J. Komarkova, K. Izydorczyk, T. Jurczak, M. Tarczynska \& M. Zalewski, 2005. Hepatotoxic cyanobacterial blooms in the lakes of northern Poland. Environmental Toxicology 20(5): 499-506.

Monchamp, M. E., F. R. Pick, B. E. Beisner \& R. Maranger, 2014. Nitrogen forms influence microcystin concentration and composition via changes in cyanobacterial community structure. PLoS One 9(1): e85573. CrossRef, Medline.

Naselli-Flores, L. \& L. Barone, 2005. Water-level fluctuations in Mediterranean reservoirs: setting a dewatering threshold as a management tool to improve water quality. Hydrobiologia 548(1): 85-99.

Padisák, J., C. S. Reynolds \& U. Sommer, 1993. Intermediate Disturbance Hypothesis in Phytoplankton Ecology. Kluwer Academic, Dordrecht.

Padisák, J., J. Köhler \& S. Hoeg, 1999. The effect of changing flushing rates on development of late summer Aphanizomenon and Microcystis populations in a shallow lake, Müggelsee, Berlin, Germany. In Tundisi, J. G. \& M. Straškraba (eds), Theoretical Reservoir Ecology and its Applications. Backhuys, Kerkwerve: 411-424.

Pawlik-Skowronska, B., T. Skowroński, J. Pirszel \& A. Adamczyk, 2004. Relationship between cyanobacterial bloom and anatoxin-a and microcystin occurrence in the eutrophic dam reservoir (SE Poland). Polish Journal of Ecology 52(4): 379-390.

Pawlik-Skowronska, B., M. Toporowska \& J. Rechulicz, 2012. Simultaneous accumulation of anatoxin-a and microcystins in three fish species indigenous to lakes affected by cyanobacterial blooms. Oceanological and Hydrobiological Studies 41(4): 53-65.

Pawlik-Skowronska, B., R. Kalinowska \& T. Skowroński, 2013. Cyanotoxin diversity and food web bioaccumulation in a reservoir with decreasing phosphorus concentrations and perennial cyanobacterial blooms. Harmful Algae 28: $118-125$.

Pearl, H. W., 2014. Mitigating harmful cyanobacterial blooms in a human- and climatically-impacted world. Life 4(4): 988-1012.

PN-ISO, 10260, 2002. Water quality. Measurement of biochemical parameters. Spectrophotometrical determination of chlorophyll-a concentration. PKN, Warsaw (in Polish).

Reynolds, C. S. \& J. W. G. Lund, 1988. The phytoplankton of an enriched, soft-water lake subject to intermittent hydraulic flushing (Grasmere, English Lake District). Freshwater Biology 19(3): 379-404.

Romo, S., J. Soria, F. Fernández, J. Ouahid \& A. Barón-Solá, 2013. Water residence time and the dynamics of toxic cyanobacteria. Freshwater Biology 58(3): 513-522.

Salmaso, N., D. Copetti, L. Cerasino, S. Shams, C. Capelli, A. Boscaini, L. Valsecchi, F. Pozzoni \& L. Guzzella, 2014. Variability of microcystin cell quota in metapopulations of Planktothrix rubescens: causes and implications for water management. Toxicon 90: 82-96.

Scheffer, M., S. Rinaldi, A. Gragnani, L. R. Mur \& E. H. van Nes, 1997. On the dominance of filamentous cyanobacteria in shallow, turbid lakes. Ecology 78(1): 272-282.

Shannon, C. E. \& W. Weaver, 1949. The mathematical theory of communication. University of Illinois Press, Urbana.

Sivonen, K. \& T. Börner, 2008. Bioactive compounds produced by cyanobacteria. In Herrero, A. \& E. Flores (eds), The 
Cyanobacteria: Molecular Biology, Genomics and Evolution. Caister Academic Press, Norfolk: 159-197.

ter Braak, C. J. F. \& P. Šmilauer, 2002. CANOCO Reference Manual and User's Guide to Canoco for Windows: Software for Canonical Community Ordination (version 4.5). Microcomputer Power, Ithaca, NY, USA.

Tonk, L., P. M. Visser, G. Christiansen, E. Dittmann, E. O. F. M. Snelder, C. Wiedner, L. R. Mur \& J. Huisman, 2005. The microcystin composition of the cyanobacterium Planktothrix agardhii changes toward a more toxic variant with increasing light intensity. Applied and Environmental Microbiology 71: 5177-5181.

Toporowska, M. \& B. Pawlik-Skowronska, 2014. Four-year study on phytoplankton biodiversity in a small hypertrophic lake affected by water blooms of toxigenic cyanobacteria. Polish Journal of Environmental Studies 23(2): 491-499.

Toporowska, M., B. Pawlik-Skowronska \& R. Kalinowska, 2014. Accumulation and effects of cyanobacterial microcystins and anatoxin-a on benthic larvae of Chironomus spp. (Diptera: Chironomidae). European Journal of Entomology 111(1): 83-90.

Verspagen, J. M., J. Passarge, K. D. Johnk, P. M. Visser, L. Peperzak, P. Boers, H. J. Laanbroek \& J. Huisman, 2006.
Water management strategies against toxic Microcystis blooms in the Dutch delta. Ecological Applications 16(1): 313-327.

Via-Ordorika, L., J. Fastner, R. Kurmayer, M. Hisbergues, E. Dittmann, J. Komarek, M. Erhard \& I. Chorus, 2004. Distribution of microcystin-producing and non-producing Microcystis sp. in European freshwater bodies: detection of microcystins and microcystin genes in individual colonies. Systematic and Applied Microbiology 27(5): 592-602.

Weithoff, G., N. Walz \& U. Gaedke, 2001. The intermediate disturbance hypothesis-species diversity or functional diversity? Journal of Plankton Research 23(10): 1147-1155.

Welker, M. \& H. Döhren, 2006. Cyanobacterial peptides nature's own combinatorial biosynthesis. FEMS Microbiology Reviews 30: 530-563.

Xu, Y., Z. Wu, B. Yu, X. Peng, G. Yu, Z. Wei, G. Wang \& R. Li, 2008. Non-microcystin producing Microcystis wesenbergii (Komárek) Komárek (Cyanobacteria) representing a main water bloom-forming species in Chinese waters. Environmental Pollution 156: 162-167.

Zohary, T. \& I. Ostrovsky, 2011. Ecological impacts of excessive water level fluctuations in stratified freshwater lakes. Inland Waters 1: 47-59. 